Original Research Paper

\title{
Pelatihan Pembuatan Pie Pisang Sebagai Makanan Khas di Desa Kandangtepus Kecamatan Senduro Kabupaten Lumajang
}

\author{
Suci Ristiyana ${ }^{1}$, Ahmad Ilham Tanzil ${ }^{1}$, Tri Wahyu Saputra ${ }^{1}$, Ika Purnamasari ${ }^{1}$ \\ ${ }^{1}$ Program Studi Agroteknologi, Universitas Jember, Jember, Indonesiay;
}

https://doi.org/10.29303/jpmpi.v3i2.1339

Sitasi: Ristiyana, S., Tanzil, A. I., Saputra, T. W \& Purnamasari, I. (2022). Pelatihan Pembuatan Pie Pisang Sebagai Makanan Khas di Desa Kandangtepus Kecamatan Senduro Kabupaten Lumajang. Jurnal Pengabdian Magister Pendidikan IPA, 5(1)

\section{Article history}

Received: 11 Januari 2022

Revised: 01 Februari 2022

Accepted: 07 Februari 2022

*Corresponding Author: Suci Ristiyana, Program Studi Agroteknologi, Universitas Jember, Indonesia;

Email : suciristi@unej.ac.id

\begin{abstract}
Desa Kandangtepus merupakan wilayah yang mayoritas masyarakatnya menanam pisang kirana, serta pemasarannya yang sudah menembus pasar ekspor. Desa Kandangtepus menghasilkan pisang yang terkenal yaitu pisang Mas Kirana. Namun di daerah tersebut belum memiliki pengolahan makanan khas dari dasar buah pisang yang bisa meningkatkan harga dari pisang Kirana di masa depan selain sebagai komoditas ekspor. Karena itu maka pengabdian ini kami memilih kegiatan pelatihan pembuatan pie pisang yang diharapkan nantinya bisa menjadi suatu makanan khas di daerah Kandangtepus dan bisa dikenal ke masyarakat luas diluar Lumajang. Pie pisang memiliki kandungan gizi yang baik untuk kesehatan tubuh manusia salah satunya untuk pencernaan, selain itu kandungan gizi yang terkandung di dalam pie pisang / 50 gr adalah sebagai berikut : kalori 158 kkal, lemak 8,05 gr, protein 1,5 gr, karbohidrat $21,3 \mathrm{gr}$, serat 1,3 gr, gula 10,7 gr, sodium $187 \mathrm{mg}$, kalium $32 \mathrm{mg}$, kolesterol $0 \mathrm{mg}$. Diharapkan dengan pembuatan pie pisang masyarakat lebih kreatif dan memiliki ketrampilan lebih sehingga bisa meningkatkan kesejahteraan masyarakat khususnya di desa tersebut
\end{abstract}

Keywords: Pisang; Mas Kirana; Pie Pisang

\section{Pendahuluan}

Komoditas hortikultura dari kelompok buahbuahan yang saat ini diperhitungkan adalah tanaman pisang. Pengembangan buah pisang memiliki tujuan yaitu memenuhi kebutuhan buah buahan seiring bertambahnya jumlah penduduk dan meningkatnya kesadaran masyarakat pentingnya gizi dimana pisang memiliki sumber vitamin, mineral dan karbohidrat. Selain itu rasa yang lezat, memiliki gizi tinggi serta harganya relatif murah, pisang juga salah satu tanaman yang memiliki prospek cerah karena di dunia hampir setiap orang gemar buah pisang (Komaryati dan Adi, 2012).
Keragaman varietas pisang di Jawa Timur sangat tinggi dan memiliki peluang untuk dikembangkan sebagai sumber peningkatan ekonomi petani. varietas pisang yang dikembangkan memiliki nilai jual yang tinggi dan disukai oleh konsumen. Pisang dapat dibedakan menjadi dua, yaitu sebagai buah meja dan olahan (Kusumo, 1996).

Desa Kandangtepus merupakan desa dengan topografi atau bentang lahan yang terbagi dua bagian yaitu dataran dengan luas 735,9 Ha dan perbukitan seluas 1.015,06 Ha (Badan Pusat Statistika Kabupaten Lumajang, 2017). Desa Kandangtepus berada di daerah kawasan Kecamatan Senduro Kabupaten Lumajang Provinsi Jawa Timur. Desa Kandang Tepus merupakan 
daerah dataran tinggi. Desa Kandang Tepus juga terkenal sebagai Kampung pisang, dimana di desa tersebut memiliki komoditas pisang terbaik yaitu pisang Kirana. Pisang Mas Kirana memiliki keunggulan daripada pisang lain yaitu bentuk dari buah pisang kirana bulat berisi, kulit buah berwarna kuning cerah, dan daging buah berwarna kuning cerah juga dengan rasa manis (Solicha,2011)

Terdapat dua kelompok tani yang tersebar di Desa Kandangtepus. Satu dari kelompok tani tersebut menjadi kelompok tani yang aktif dalam meningkatkan perkembangan pisang mas Kirana. Kelompak tani ini mendapatkan fasilitas rumah kemas dari pemerintah untuk mengolah hasil panen secara baik.

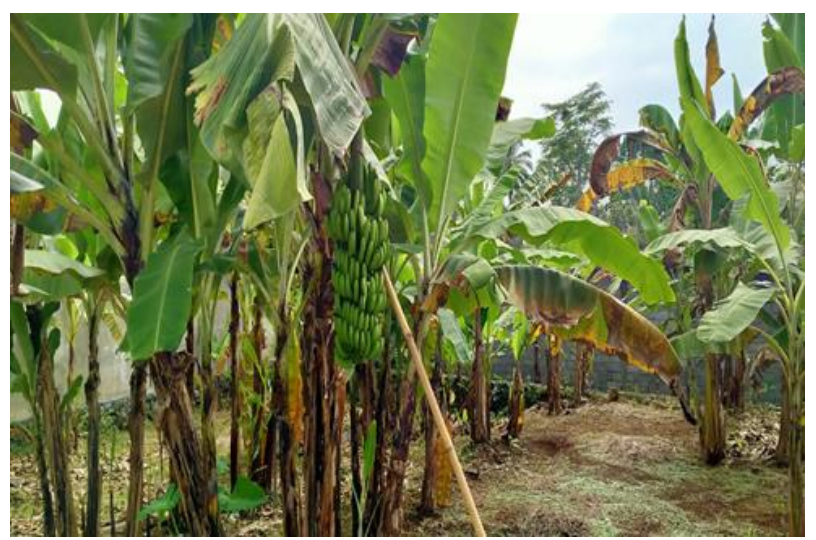

Gambar 1. Pemeliharaan tanaman pisang mas Kirana

Pisang Kirana dipilih oleh kebanyakan masyarakat di Desa Kandangtepus Kecamatan Senduro untuk dibudidayakan karena pisang jenis ini mudah untuk dibudidayakan, serta sesuai dengan kondisi iklim dan cuaca daerah setempat. Tanaman pisang mas Kirana oleh masyarakat setempat banyak dibudidayakan di pekarangtegalan dan di sela perkebunan rakyak atau tanaman kopi atau sebagai tanaman tumpang sari. Kondisi lingkungan yang mendukung untuk pertumbuhan pisang mas, panen pisang mas dapat dilakukan sepanjang tahun.

Produsen pisang kirana di Kabupaten Lumajang, membagi pisang Kirana berdasarkan jenis kategori yaitu kualitasnya. Pada jenis pisang Kirana dengan kualitas B maka akan di jual di pasar tradisional atau pasar. Untuk pisang dengan kualitas A maka akan didistribusikan lalu dijual ke pasar swalayan di kota besar di seluruh Jawa Timur bahkan Indonesia (Frannoto, 2011).
Berdasarkan hasil keputusan dari Mentri Pertanian No.516 / Kpts / SR / 120 / 12 / 2005, kandungan gizi yang dimiliki pisang mas kirana cukup tinggi, sehingga konsumen banyak yang menyukainya terutama bagi mereka yang sedang program diet. Dimana kandungan gizi yang ada di pisang mas kirana terdiri dari : 99 kalori, protein 1,2 gram, lemak 0,2 gram, karbohidrat $25,8 \mathrm{mg}$, serat 0,7 gram, kalsium $8 \mathrm{mg}$, fosfor $28 \mathrm{mg}$, besi $0,5 \mathrm{mg}$, vitamin A $44 \mathrm{RE}$, vitamin B $0,08 \mathrm{mg}$, vitamin $\mathrm{C}$ sebanyak $3 \mathrm{mg}$ dan air 72 gram (Nawangsih, 2018)

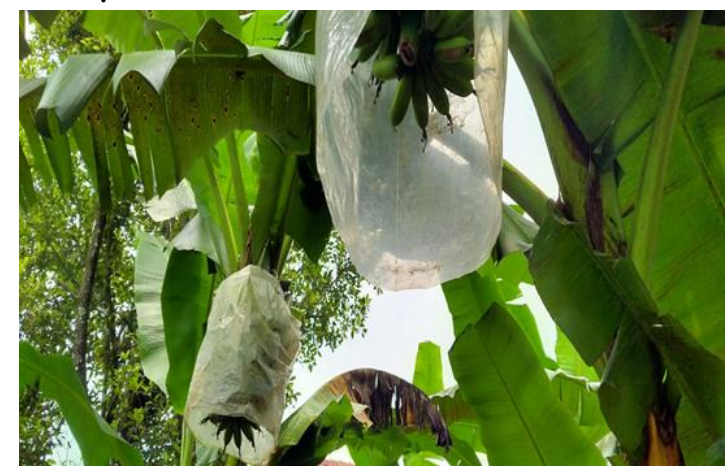

Gambar 2. Pisang Mas Kirana yang di"brongsong"

\section{Metode}

1. Diskusi

Diskusi dilakukan antara tim pelaksana program pengabdian masyarakat dengan Kepala Desa Kandangtepus dan perwakilan petani.. Diskusi dimaksudkan untuk mensosialisasikan tentang rencana mengenalkan metode pembuatan pie pisang untuk makanan khas di desa tersebut.

2. Peninjauan lokasi

Peninjauan lokasi ditujukan untuk menentukan tempat yang dijadikan tempat sosialisasi. Lokasi yang dipilih pada kegiatan ini adalah aula terbuka Desa Kandangtepus.

3. Penyediaan sarana dan prasarana.

Menyediakan sarana dan prasarana untuk pembuatan pie pisang dengan alat dan bahan antara lain pisang, tepung terigu, pisau, talenan, alat pengering, alat penghancur atau penggiling, ayakan atau saringan, plastic, oven.

4. Pembuatan pie pisang 
Sosialisasi serta pelatihan pembuatan pie pisang Bersama dengan ibu ibu PKK di Desa Kandang Tepus Lumajang.

\section{Hasil dan Pembahasan}

Kegiatan pengabdian ini bertujuan agar masyarakat di daerah Kandangtepus khususnya ibu ibu PKK memiliki tambahan penghasilan dari pemangfaatan panen pisang kirana yang biasanya hanya langsung dijual ke tengkulak bisa diolah dahulu menjadi makanan khas daerah Kandang tepus sehingga memiliki harga yang lebih tinggi.

Faktor lain yang mendukung banyaknya masyarakat untuk membudidayakan pisang Kirana adalah waktu panen yang begitu cepat yakni 45 hari setelah jantung pisang mekar atau ketika pisang sudah berumur 12-14 bulan setelah tanam benih anakan. Pesatnya perkembangan pisang mas Kirana di Desa Kandangtepus Kecamatan Senduro telah mendorong tumbuhnya penangkar benih pisang yang pada umumnya perbanyakan dilakukan menggunakan bonggol. Usaha tani pisang di Desa Kanangtepus Kecamatan Senduro sudah berlangsung turun temurun, namun untuk usaha tani pisang mas Kirana sudah sekitar 11 tahunan. Pisang mas Kirana telah dilepas oleh Menteri Pertanian sebagai varietas unggulan. Kabupaten Lumajang

Petani pisang mas Kirana di Desa Kandangtepus menggunakan tenaga kerja dalam keluarga pada saaat perawatan pisang mas Kirana saja. Untuk pengolahan lahan, pembuatan jurangan, dan pemasaran pisang mas Kirana di Desa Kaandangtepus menggunakan tenaga kerja dari luar keluarga dengan upah Rp.1000,- tiap jurang. Pemasaran pisang mas Kirana di Desa Kandangtepus dilakukan oleh lembaga pemasaran yang terdapat di Desa tersebut. Lembaga pemasaran yang terdapat di Desa Kandangtepus meliputi pedagang pengumpul desa dan pedagang pengumpul kabupaten. Petani pisang mas Kirana di Desa Kandangtepus terbagi dalam dua kelompok tani, yaitu kelompok tani Raja Mas dan kelompok tani Sumber Mas.

Kelompok tani Raja Mas merupakan kelompok tani yang aktif dalam setiap kegiatan peningkatan pisang mas Kirana baik dari hasil produksi maupun kualitas pisang mas Kirana. Kelompok tani raja mas beranggotakan 37 petani pisang mas Kirana yang berada di Desa Kandangtepus. Kelompok tani di Desa
Kandangtepus sudah mendapatkan sertifikat produk prima 3 dan sertifikat global GAP Good Agricultural Practices dunia. Sertifikat yang didapat oleh kelompok tani mempermudah petani-petani yang tergabung didalamnya dalam memasarkan pisang mas Kirana ke pasar lokal maupun pasar luar negeri.

Kegiatan pengabdian ini dimulai dengan pertemuan bersama para pamong desa dimana terdapat kepala desa dan perangkat desa. Kegiatan yang dilakukan pada awal program pengabdian desa binaan, yaitu sosialisasi program pengembangan pie pisang kepada anggota perangkat desa. Kegiatan ini diawali dengan diskusi di Balai Desa Sumber Tengah bersama Kepala Desa dan jajarannya. Diskusi ini mencakup permohonan ijin untuk melaksanakan program pengabdian sekaligus menyampaikan rangkaian kegiatan yang tercakup dalam program.

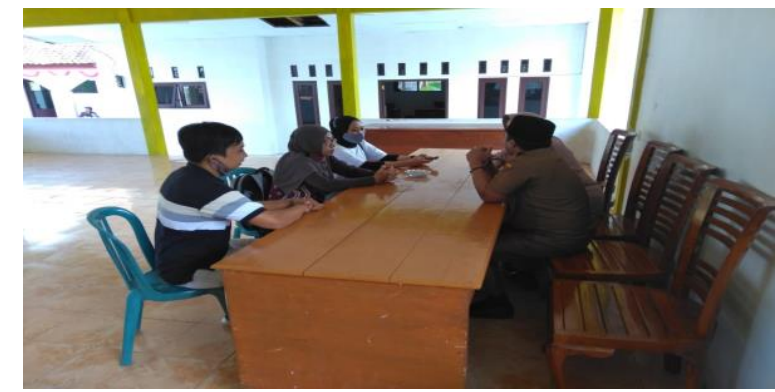

Gambar 3. Diskusi bersama kepada desa dan perangkat desa.

Sosialisasi pembuatan pie pisang diikuti oleh ibu ibu PKK di Desa Kandang Tepus. Pada sosialisasi ini ibu-ibu PKK langsung mencoba pembuatan pie tersebut dengan dibantu dosen serta mahasiswa. Pembuatan pie ini membutuhkan waktu sekitar 1.5 jam. Kegiatan tersebut dibuka dengan pengenalan pie pisang dan cara pembuatannya pie secara teori oleh dosen dan mahasiswa.

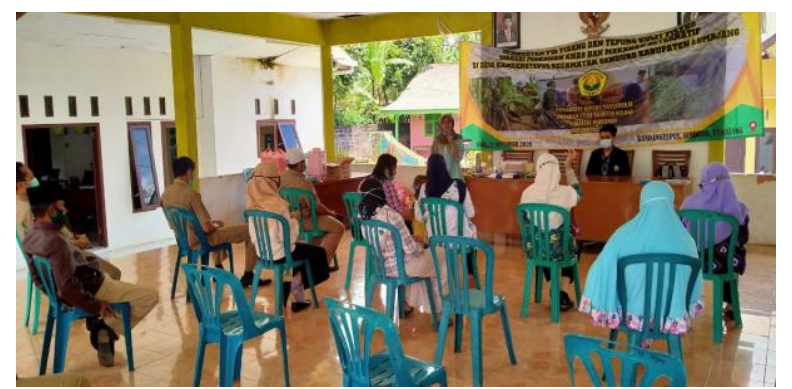

Gambar 4. Sosialisasi terkait pembuatan pie 


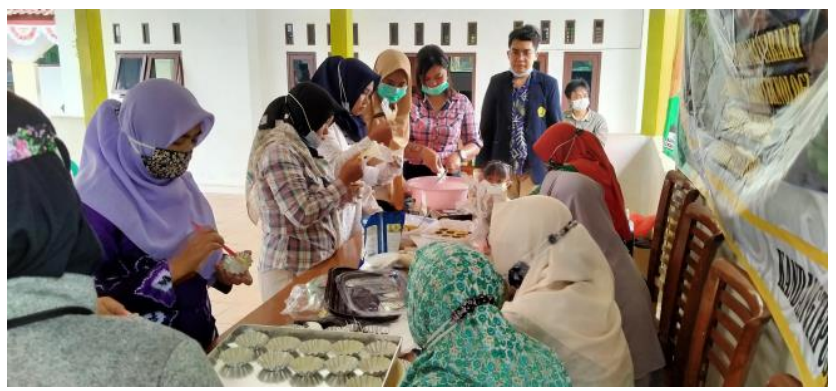

Gambar 5. Pembuatan pie pisang Bersama ibu-ibu PKK

Selain itu kegiatan tersebut juga diisi dengan sesi tanya jawab bersama ibu-ibu PKK terkait pembuatan pie pisang tersebut, ibu - ibu di acara tersebut sangat antusias, selain belajar untuk membuat pie mereka juga bisa langsung mencoba mecicipi rasa dari pie pisang yang sudah mereka buat.

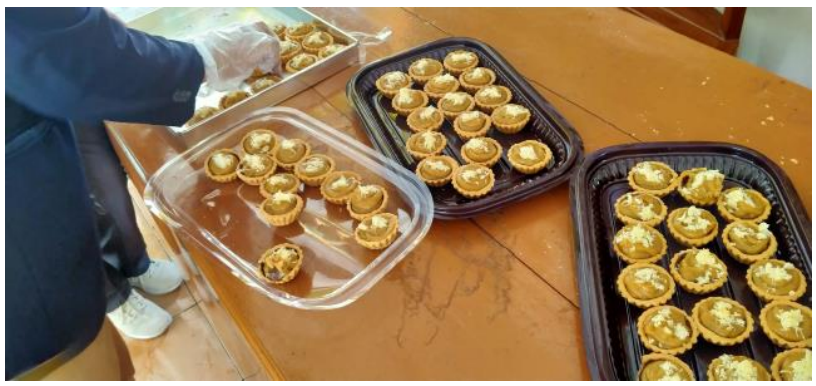

Gambar 6. Hasil pembuatan pie pisang

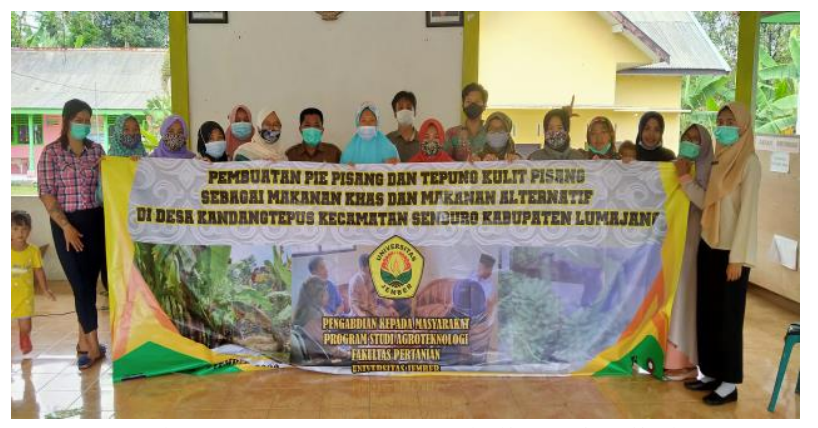

Gambar 7. Peserta pengabdian pie di desa Kandangtepus

\section{Kesimpulan}

Kegiatan sosialisasi dan pelatihan pembuatan pie pisang Bersama para ibu-ibu PKK sangat antusias dalam mengikuti seluruh rangkaian kegiatan dalam program ini baik tahap sosialisasi maupun pelatihan. Pada sesi diskusi beberapa pertanyaan banyak dilontarkanterkait masalah bagaimana membuat pie lebih renyah dan tidak mudah basis. Kegiatan ini mampu mendorong dan meningkatkan kesadaran kelompok ibu ibu PKK dalam memanfaatkan pisang kirana untuk menjadi suatu makanan khas di daerah desa Kandangtepus bahkan di luar Lumajang.

\section{Saran}

Dengan adaya kegiatan ini diharapkan masyarakat setempat dapat mengembangkan hasil panen pisang Kirana dan pemberian bantuan alat dari pemerintah setempat secara optimal sehingga masyarakat memiliki tambahan penghasilan untuk meningkatkan kesejahteraan masyarakat Kandangtepus di masa depan terkait pembuatan pie pisang.

\section{Daftar Pustaka}

Badan Pusat Statistika Kabupaten Lumajang, 2017. Kecamatan Senduro Dalam Angka, Katalog BPS 35080.1722. BPS Kabupaten Lumajang: Lumajang.

Komaryati dan Adi,S. 2012. Analisis FaktorFaktor yang Mempengaruhi Tingkat Adopsi Teknologi Budidaya Pisang Kepok (Musa paradisiaca) di Desa Sungai Kunyit Laut Kecamatan Sungai Kunyit Kabupaten Pontianak. J. Iprekas : 53-61.

Kusumo, S., R.E. Nasution, H. Sunarjono, F.A. Bahar, dan S. Pratikno. 1996. Koleksi, konservasi dan evaluasi plasma nutfah pisang. Laporan Hasil Penelitian RUTI. Proyek Pusat Penelitian Ilmu Pengetahuan dan Teknologi Serpong. hal 40.

Solicha, Zumrotun. 2011. Pisang Mas Kirana Dapat Kurangi Stress. Diakses dari https://jatim.antaranews.compada . Diakses tanggal 11 November 2011.

Frannoto, 2011. Sang Primadona dari Lumajang. http://www.eastjavatraveler. com. Diakses tanggal 31 Desember 2014.

Nawangsih. 2018. Analisis Potensi Daya Saing Pemasaran Produk Unggulan Pisang Mas Kirana. STIE Widya Gama : Lumajang. 